Six', partly on the grounds that the forensic evidence used to convict them for pub bombings in the $1970 \mathrm{~s}$ was flawed.

Mansfield argued that although the ten bands used to compare Deen's DNA samples with those of the victim matched perfectly, the potential significance of discrepancies in two other bands had not been sufficiently explained to the jury.

$\mathrm{He}$ also argued that one of the prosecution's expert witnesses, as well as the judge, had confused two different sorts of probability. One is the probability that DNA from an individual selected at random from the population would match that of the semen taken from the rape victim, a calculation generally based solely on the frequency of different alleles in the population.

The other is the separate probability that a match between a suspect's DNA and that taken from the scene of a crime could have arisen simply by chance - in other words that the suspect is innocent despite the apparent match. This probability depends on the other factors that led to the suspect being identified as such in the first place.

During the trial, a forensic scientist gave the first probability in reply to a question about the second. Mansfield convinced the appeals court that the error was repeated by the judge in his summing up, and that this slip - widely recognized as a danger in any trial requiring the explanation of statistical arguments to a lay jury - justified a retrial.

In their judgement, the three appeal judges, headed by the Lord Chief Justice, Lord Farquharson, explicitly stated that their decision "should not be taken to indicate that DNA profiling is an unsafe source of evidence".

Nevertheless, with DNA techniques being increasingly used in court cases, some forensic scientists are worried that flaws in the presentation of their statistical significance could, as in the Deen case, undermine what might otherwise be a convincing demonstration of a suspect's guilt.

Some now argue, for example, that quantified statistical probabilities should be replaced, wherever possible, by a more descriptive presentation of the conclusions of their analysis. "The whole issue of statistics and DNA profiling has got rather out of hand," says one.

Others, however, say that the Deen case has been important in revealing the dangers inherent in the 'prosecutor's fallacy'. They argue that this suggests the need for more sophisticated calculation and careful presentation of statistical probabilities.

"The way that the prosecution's case has been presented in trials involving DNAbased identification has often been very unsatisfactory," says David Balding, lecturer in probability and statistics at Queen Mary and Westfield College in London. "Warnings about the prosecutor's fallacy should be made much more explicit. After this decision, people are going to have to be more careful."

David Dickson

\title{
France gives broader role to defence research panel
}

Paris. The French minister of defence, François Leotard, last week expanded the Scientific Council for Defence - the committee that advises the government on defence research - to include more representatives from universities, public research organizations and private industry.

Leotard described the main purpose of this move as being to make "tighter and more coordinated links" between civil and military research. But it is also being seen as a step towards a single integrated approach to technology policy, covering both the civilian and the military sector.

The head of the enlarged council will be André Giraud, a former head of the French Atomic Energy Commission (CEA). Giraud himself created the council in 1986 when he was minister of defence in the conservative government of Jacques Chirac.

Since then, its main activity has been to study specific areas of weapons technology at the request of ministers. In its expanded role, the council will monitor all advances in research for their potential impact not only on new weapons systems but also on other activities, including civilian industry.

This change highlights two trends. One is that the French military is turning to civilian science because, according to Leo-

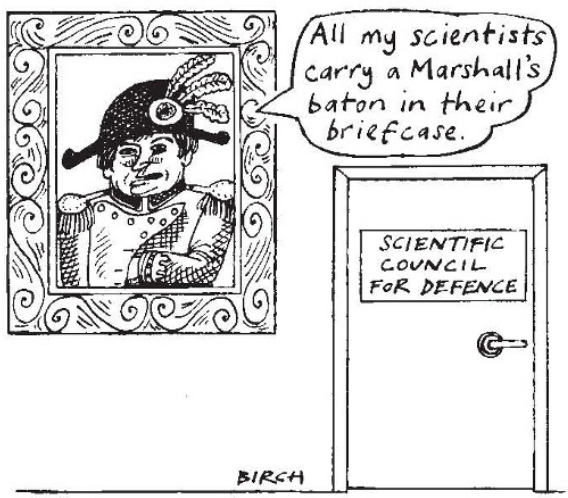

tard, it has belatedly recognized that, despite having given priority to its own research efforts in the past, France (like the rest of Europe) still lags behind the United States in fields such as space and computer technology and advanced avionics.

The French military can no longer afford to carry out such research on its own, particularly now that defence budgets are falling, and is therefore turning both to the civilian sector and to its European colleagues.

The other factor behind the decision to expand the scope of the council's work, says Alain Quenzer, its permanent secretary, is that France is broadening its concept of national defence beyond that of providing weapons systems to defend its territory, to protecting its "image and international influence, including its economic strength and science base".

In the short term, it is also clear that France hopes to save some of the 104,000 jobs expected to disappear in the arms industry before 1997 by converting parts of the military-industrial complex to civilian goals.

Behind both trends are the implications of the end of the Cold War. One concern in France is that Europe will end up perched on a US-Russian axis. To avoid this, France seems likely abandon its autonomy in weapons systems and support a European effort; a recent report to the government recommended that it share the cost of developing weapons (except nuclear) and other military technology with its European partners.

Observers in Paris feel that both initiatives are likely to propose increased funding for 'dual' high-technology research of both military and commercial interest. They may also lead to a reappraisal of the grands programmes technologiques in nuclear science, aeronautics and space, which still absorb much of France's research spending.

Quenzer says, for example, that although the grands programmes have been successful, the emphasis laid on them has led to neglect of other industrially important areas such as lasers and robotics. He says that a reorganization of the existing programmes is being discussed in order to produce greater industrial benefits, given that their political and strategic importance has been reduced by recent geopolitical changes.

The new council's first task will be to evaluate the importance of biology to defence. Quenzer says that France is concerned that developing countries could develop biological weapons, using advances in genetic engineering, for example, to produce cheaper and simpler weapons than nuclear bombs

But the government's moves are not without their critics. François Clapier, a researcher at the CNRS' Institut de Physique Nucléaire at Orsay, and secretary of the Group of Scientists for Nuclear Disarmament, says he is disappointed that France has not grasped the opportunities offered by the end of the Cold War to boost civilian research.

Clapier says France should be reducing military spending, rather than increasing its weapons research effort and extending it into new areas such as biology. He is also worried that "dual" research may turn out to be a euphemism for "handing control of the civil science budget to the military".

Declan Butler 